International Journal of Instruction e-ISSN: 1308-1470 • www.e-iji.net

Article submission code: 20200711055548

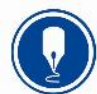

October $2021 \bullet$ Vol.14, No.4

p-ISSN: 1694-609X

pp. 695-712

Received: 11/07/2020

Revision: 16/04/2021
Accepted: 10/05/2021

OnlineFirst: 26/08/2021

\title{
The Effectiveness of Design Thinking in Improving Student Creativity Skills and Entrepreneurial Alertness
}

\section{Laurensia Claudia Pratomo}

Sebelas Maret University, Indonesia, laurensiaclaudiap@gmail.com

\section{Siswandari}

Prof., Sebelas Maret University, Indonesia, siswandari@staff.uns.ac.id

\section{Dewi Kusuma Wardani}

Dr., Sebelas Maret University, Indonesia, dewikw70@yahoo.com

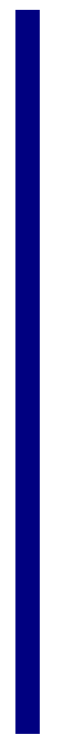

This research aims to examine the effectiveness of entrepreneurship learning with the Stanford D School design thinking approach and to make students more actively involved in learning activities so that their learning experiences can develop creative skills and entrepreneurial alertness. The underlying theory of the design thinking approach comes from the Experiential Learning Theory. This quasi-experiment was conducted by distributing questionnaires before and after the implementation of the learning approach. The research samples was students of the marketing expertise program from vocational schools, consisted of 60 students with Stanford D School design thinking approach and 60 students with teachercentered learning approach. The data were analyzed by the Independent Sample tTest and Paired Sample t-Test with SPSS 23 program. The results show that there are significant differences in creativity skills and entrepreneurial alertness between the experimental and the control class, and there are significant differences in the creativity skills and entrepreneurial alertness of the experimental class after receiving entrepreneurship learning with the design thinking approach. This gap can be overcome after students receive entrepreneurship learning using design thinking approach. The results of this study prove that Stanford D School design thinking can be applied to entrepreneurship learning, especially in vocational schools.

Keywords: design thinking, Stanford D School, entrepreneurship learning, creativity skills, entrepreneurial alertness, learning model

\section{INTRODUCTION}

Data from the Ministry of Cooperatives and SMEs (2020) shows that global economic uncertainty has an impact on the Indonesian economy, one of which is Indonesia's ability to create jobs that are limited to 2 million labor force per year. Meanwhile, the data from the Central Statistics Agency shows 7.05 million of Indonesia's

Citation: Pratomo, L. C., Siswandari., \& Wardani, D. K. (2021). The effectiveness of design thinking in improving student creativity skills and entrepreneurial alertness. International Journal of Instruction, 14(4), 695-712. https://doi.org/10.29333/iji.2021.14440a 
unemployment. The level of entrepreneurship in Indonesia is still relatively low, $3.5 \%$ of the total population, whereas the number of entrepreneurs in other countries such as Malaysia (5\%), Singapore (7\%), China (10\%), Japan (11\%). and the U.S. (12\%) is much higher. Apart from the limited employment opportunities in Indonesia, World Economic Forum (2018) in the Future of Jobs Survey states that half of the current work activities can be automated in 2055 like replacing human roles and responsibilities. Vocational school students as prospective workers will face this challenge in the future. Singh (2006: 7) explained that affective abilities allow humans to solve the problems they face because although technology can replace human cognitive abilities, it cannot replace human affective abilities. Creativity and entrepreneurship skills are affective abilities that can become provisions for students after graduation (Val, E. et al., 2019) and this affective ability can be built, one of which is through interaction between students and their teacher in the learning process.

However, vocational school students who have been prepared to work according to their fields of expertise (UU RI No. 20, 2003) are the highest contributor to unemployment in Indonesia since 2017 (BPS, 2019). Entrepreneurship learning aims to teach life skills that can prepare students for an uncertain future. According to the Ministry of Education and Culture (2017), these skills include problem-solving, collaboration, empathy, collaboration, communication, and the ability to accept failure as part of the student growth process. In addition to skills, entrepreneurial alertness is needed to train students' abilities to identify opportunities and, hopefully, can strengthen individual entrepreneurial intentions so that it is likely to grow new entrepreneurs (Hamidi, et al., 2008).

Creativity skills and entrepreneurial alertness can be trained through entrepreneurship learning in vocational schools. Students who receive entrepreneurship learning can develop not only technical skills (Linton \& Klinton, 2019) but also insights, abilities, and skills (Boyles, 2012). As with creativity that can be developed continuously (Dyer, et al., 2011: 21), entrepreneurial alertness is not limited to the number of students who have it, but, through an appropriate entrepreneurship learning scheme, entrepreneurial alertness can be developed continuously (Valliere, 2013).

Teachers tend to choose a teacher-centered approach in teaching entrepreneurship on all topics because they consider it easier to manage learning (Garrett, 2008). According to Drapeau (2014), teachers who tend to spend more time delivering learning material in class and spend less time in student thinking processes (improving thinking skills and creative processes) make an uncreative learning environment. This opinion is evident from the results of a pre-research questionnaire which shows that students find entrepreneurial learning to be boring because learning activities were teacher-centered and they are not given the freedom to develop ideas and skills during entrepreneurship learning. The success of the learning process partly depends on the ability of teachers to design learning according to student needs (Blenker, et al., 2011) and learning models that can train and improve student skills. To address these challenges, the Stanford D School learning model can be applied in entrepreneurship learning. Entrepreneurship learning can train the creativity skills and entrepreneurial alertness (Valliere, 2013) 
needed by students majoring in online business and marketing in marketing their products during school and after graduation. Through Stanford D School design thinking learning, students are always trained to be sensitive to their environment and be able to provide useful solutions (not just solutions in entrepreneurial learning tasks) and benefits for other people in real life.

Design thinking was originally the working way for a designer; they faced various problems over the years and subsequently designed and developed complex professional practices in their fields to solve the problems (Dorst, 2011). Previous research found that design thinking can improve student creativity skills and critical-thinking skills (Aflatoony \& Wakkary, 2015) but not collaboration skills (Val, E. et al., 2019). Design thinking can foster entrepreneurial interest, but there are findings explaining that the design thinking process does not affect creativity skills and innovative opportunities but incremental innovation based on individual knowledge (Nielsen, et al., 2013).

Nevertheless, the application of design thinking in entrepreneurship education, especially in vocational schools, is very limited because design thinking is most widely used in the world of business and product and service design, so there needs to be more attention to design thinking in education (Henriksen, D. et al., 2017). Design thinking can develop the creative skills of people who are engaged in business and design as well as vocational students who need a "platform" to develop their skills. Compared to senior high schools that emphasize theoretical aspects, vocational schools emphasize training and practical activities for their students so that the learning approaches and methods used by the teacher greatly influence the goals to be achieved. The researcher in this case applied design thinking as an approach to learning by integrating the Stanford D School learning model. The Stanford D School model is considered simpler for secondary school students (Sarooghi, et al., 2019), including vocational schools in Indonesia. In addition, the Stanford D School model is considered able to introduce design thinking to students (Tu, et al., 2018; Val, E. et al., 2019).

Design thinking is one of the appropriate learning schemes in developing student creativity skills and entrepreneurial alertness (Val, E. et al., 2017; Val, E. et al., 2019). According to Aflatoony \& Wakkary (2015), design thinking is applied to make students creative thinkers. The learning process that involves problems can encourage students to develop their skills (Saputra, et al., 2019). This approach allows them to think critically and independently in analyzing problems and establish communication and collaboration with others to creatively find solutions and solve the problems. During the design thinking process, students also learn to look for opportunities based on the surrounding phenomena leading to opportunity recognition and entrepreneurial alertness. In addition to being able to practice entrepreneurial skills and alertness, the honed 21st-century skills will also better prepare students for the workforce. The application of the Stanford D School design thinking model in entrepreneurship subjects is expected to improve student creativity skills and entrepreneurial alertness. Better creativity and opportunity recognition skills will more likely make students entrepreneurs (Hamidi, et al., 2008). Due to the limited research on design thinking in education, the researcher tried to explore the effect of design thinking with the Stanford 
D School model in entrepreneurship subjects in vocational schools on the student creativity skills and entrepreneurial alertness. The results of this research can be used as a consideration to determine policies regarding learning approaches and models in Indonesia. How can Stanford D School design thinking be applied in education, especially in entrepreneurship learning? This research answers and provides a solution to this question.

\section{Context and Review of Literature}

\section{Stanford D School Design Thinking}

Design thinking was first introduced by Peter G. Rowe in 1987 in his book entitled "Design Thinking". The book focuses on design thinking in architecture and urban planning (Rowe, 1987). However, design thinking had also begun to be used in the field of education. Since 1980, Stanford University, which initiated the practice of design thinking, has continued to do development at the Hasso Plattner Institute of Design or "d.school". In design thinking, there is a systematic process collaboration with humans as the center of its users (Luka, 2014). Design thinking is created through a planned process so that it can finally produce a condition expected by humans (Dolak, et al., 2013). Design thinking has a distinction because, through the work process of a designer, it helps individuals produce, teach, learn, and apply systematic humancentered techniques to solve problems in everyday life creatively and innovatively (Dam, 2019).

There are seven design thinking themes classified based on "what" (content) and "how" design thinking is taught in various disciplines (Wrigley, Mosely, \& Tomitsch, 2018), namely (1) introductory, (2) start-ups, (3) leadership and implementation, (4) HumanCentered Design (HCD), (5) social innovation, (6) design education, and (7) business strategy design. This research uses a design thinking approach with the Stanford D School model that can be classified into the introductory theme (Wrigley, C., Mosely, G., \& Tomitsch, M., 2018). Compared to "what" is produced (content), Stanford D. School places more emphasis on "how" students work creatively, because Stanford D School learning activities are focused on helping someone strengthen their creativity skills that are applied in everyday life (D.School, 2019). Stanford D School design thinking is a methodology for implementing creative problem-solving learning which consists of five processes of the 5-stage model, namely empathize, define, ideate, prototype, and test. In the context of education, design thinking is a practice of special design exercises aimed at encouraging innovation by increasing student creativethinking skills (Aflatoony \& Wakkary, 2015). A new learning approach that can instill 21 st-century skills in every individual, especially those who have expertise from various disciplines and practices (Wrigley, C., et al., 2018), because to solve life problems requires an approach that can connect various disciplines or multidiscipline ( $\mathrm{Li}, \mathrm{R}$., et al., 2019).

Design thinking approach is a learning process based on experience (Deutschmann \& Botts, 2015) and uses a human approach to explore the problems and needs of its users (Luka, 2014). The students' creative thinking abilities which are different from one 
another require a learning condition involving a learning experience, so that the potential of creative thinking can develop (Corebima, A. D. et al., 2017). The distinction of the design thinking approach, including the Stanford D School model, is that it is non-linear and iterative, which means that the design thinking process can be repeated at certain stages (Dam \& Siang, 2019) to provide students the opportunities to explore. The theory is the basis for the Stanford d design thinking approach. School is David Kolb's theory of experiential learning, which involves students' new experiences resulting in a process of observation or reflection that can guide them to create concepts and use their theories to solve problems (Nasution, 2017: 111).

\section{Entrepreneurship Learning with Design Thinking}

Entrepreneurship learning is a process that aims to transfer concepts and skills to individuals to identify new business opportunities and achieve self-confidence so that they benefit from the opportunities (McIntyre, J., \& Roche, 1999). Entrepreneurship learning is classified as one of the components in the entrepreneurial ecosystem to enhance new businesses (Van Gelderen, et al., 2015). Through entrepreneurship learning in schools, it is hoped that someday students will be able to become successful entrepreneurs (Igwe, et al., 2019) or work in other fields but still implement their entrepreneurial competencies such as to be critical, creative, never give up, have initiative, dare to face risks, and innovative. An acceptable and understandable learning approach is needed by senior high school students (Val, E. et al., 2019) so that design thinking can meet this need because it includes stages of empathize, define, ideate, prototype, and test to develop creativity and entrepreneurial alertness (Aflatoony \& Wakkary, 2015).

The implementation of entrepreneurship learning with Stanford D School approach (Aflatoony \& Wakkary, 2015; Henriksen, D. et al., 2017; Val, E. et al., 2019) includes empathize, define, ideate, prototype, and test. In this case, the researcher uses the design thinking stage by designing the learning process according to the needs of students and the applicable curriculum so that learning objectives can be achieved. Applying marketing promotional media is one of the basic competencies students will learn in entrepreneurship learning. Besides practicing creativity and entrepreneurial alertness, the Stanford D. School entrepreneurship learning must yield products, media, prototypes, policies, or solutions as a form of the learning process. Students play an important role in achieving the learning objective, where they must be directly involved in the learning process while the teacher only becomes a guide or facilitator to direct and help students during learning.

In the first stage, empathize, students are invited to understand the problem to be solved. They need to be involved directly in the environment where the problem occurs to understand the experience and increase their empathy (Aflatoony \& Wakkary, 2015). If it is not possible, teachers can invite the parties related to the problem or the users. Through this empathy process, designers or researchers can prioritize the needs of the users. The empathize stage also provides useful information for the following stages and to develop the understanding of users, user needs, and problems that form the basis of product development (D.School, 2019). 
The second stage is define, where all the information obtained by students at the empathize stage is collected, and the students conduct analysis and synthesis of the problem to find out the core problem (Val, E. et al., 2019). It is to be noted that the problem must be human centered and not personal or other parties' interests. The define stage helps students gather ideas that are useful in solving problems. At the ideate stage, students have started to produce an idea and are challenged to think of new solutions "out of the box" to solve the user problems. Students should obtain various ideas or solutions to this problem and choose some of these solutions to find the best way to solve or avoid problems (Henriksen, D. et al., 2017).

At the prototype stage, students produce an output or outcome that can be formed with a minimalist design or prototype (The output is in the form of promotional media for marketing promotion of school mini-market products in the form of wall posters and digital leaflets) to find out whether the solution is effective to solve the problem. This process can also take the form of prototype planning, digital design, or physical design (D.School, 2019). This stage is called the experimental stage because students need to test the design and evaluate the user experience. In the end, students get a better idea because of the obstacles that occur during the design trial. At the test stage, the design students have obtained is tested by the user and the results of the evaluation carried out are an iterative process (Val, E. et al., 2019). The results obtained during the test can be used to explain the existing problems, informing them, among others, user understanding, conditions of use, and user response. This stage allows changes and improvements to the product to get an understanding of the product and the users.

Increased creativity skills can be seen not only through new creative ideas generated by students, but also when students are digging deeper into ideas, listening to one's "inner voice", openness, and courage to explore ideas. Three dimensions used to measure students' entrepreneurial alertness in entrepreneurship learning with Stanford D School design thinking are alert scanning and search, alert association and connection, and evaluation and judgment (Tang, et al., 2012). According to Tang, et al. (2012), student's alert scanning and search ability is obtained through the process of building information and searching for new ideas around them, especially in arousing creativity Tang, et al., (2012); Piirto, J., 2011). Students' alert association and connection abilities are obtained by interpreting new information and comparing it with group or association information and other connections for consideration, this ability is used by students in connecting useful information in everyday life (Tu, et al., 2018). Students have evaluation and judgment abilities when conducting assessments and estimation of opportunities based on the information they have (Tang, et al., 2012). This process continues to be experienced by students even when receiving criticism and suggestions from users who try to use their prototypes (Val, E. et al., 2019). Based on the non-linear and iterative design thinking process, students can repeat the particular design thinking process when trying to improve and refine the design according to their needs, such as the empathy stage to understand again the user and explore other alternative solutions to perfect the prototype. 


\section{Creativity Skills}

According to Vygotsky (1967), creativity is every human action that results in a new thing, regardless of whether what is contributed is a physical object or a mental or emotional construction that lives within the creator and is known by him. Creativity is one of the skills needed in the 21 st century because creativity skills enable someone to solve problems through creative ideas, communication, cooperation, and using information and digital technology (Piirto, 2011). Creativity has been identified as a major component in entrepreneurship because an entrepreneur must be able to recognize opportunities, generate ideas, and innovate; therefore, creativity, innovation, and entrepreneurship cannot be separated (Zampetakis, et al., 2011).

Creativity can be interpreted as cognitive skills that can provide solutions to problems and create something that has benefits and novelty (Hu, et al., 2018). There are four levels of creativity (UCLES, 2019) including (1) big-c creativity or high creativity (describing figures whose inventions have transformed the discipline), (2) pro-c creativity (this creativity requires time and efforts in developing innovation), (3) little-c creativity (relating to an action or behavior that is flexible, intelligent, and new in daily life), and (4) mini-c creativity (novelty and individual interpretation of experiences, actions, and events). Despite the levels of creativity, the boundaries of creativity can be blurred and are not limited to age because everyone can have their own categories of creativity. Unfortunately, according to Drapeau (2014: 5), many students think that they cannot achieve creativity and only a few people can have it. They think that creativity only includes big-c and creativity is what students have in arts. When they realize that to have creativity skills does not mean to be a big-c person, they can access and even optimize their creativity.

According to Kemendikbud (2017), creativity skills are classified as one of the higherorder thinking skills (HOTS), even above critical-thinking skills. Presseisen's HOTS (Presseisen, B. Z., 1985) include critical thinking, creative thinking, problem solving, and decision making, but, in the view of Krulik and Rudnick's Taxonomy (Krulik \& Rudnick, 1999), HOTS include critical and creative thinking. On the other hand, Revised Bloom's Taxonomy (Anderson, L.W. \& Krathwohl, D.R., 2001) includes the ability to analyze, evaluate, and create. One of the abilities that must be possessed by students in the learning model used in this research is the ability to create (Revised Bloom's Taxonomy C6). When associated with Krulik and Rudnick's Taxonomy, the ability to create is classified at the creative level. Based on this, the creativity skills of students can be developed through, one of which, creativity training in schools, in this case on the creative product and entrepreneurship subject.

Entrepreneurship learning with Stanford D. School design thinking tries to train student creativity skills. To be creative and innovative is related to not only revolutionary ideas or discoveries that can change the world view, but also, in this case, student creativity leading to the process of individual growth to be achieved through the insights they gain (UCLES, 2019). This creativity can sometimes be in the form of ideas and connections between knowledge (e.g., linkages between subjects) created by students. Student creativity can also describe one's learning ability, which then creates a personal 
understanding so that it cannot be expressed directly to others. Besides, the ability to solve problems in daily life using own ideas is the real form of creativity.

This research measures students' creativity skills using assessment instruments adapted to the curriculum. Students in groups will be assessed at each stage of Stanford D School design thinking by the teacher. Also, the assessment of student creativity is measured based on the achievement or level of success of students in achieving entrepreneurial learning goals, namely producing marketing promotion media. The input and responses of mini market users are considered in giving student assessments.

\section{Entrepreneurial Alertness}

Research on entrepreneurial alertness was first carried out by Kirzner in 1973. His findings turned into the entrepreneurial alertness theory that has continued to develop to date. Kirzner stated that entrepreneurial alertness plays a role in helping entrepreneurs to be more aware and able to see the gaps and opportunities with limited instructions in various ways (Ghasemi \& Rowshan, 2016; Hu, R. et al., 2018; Tang, et al., 2012). Entrepreneurial alertness encourages individuals to grow opportunity recognition, especially those that have been ignored. However, the one's ability of opportunity recognition is influenced by his existing knowledge and information because, after the information is collected, he will try to change and develop it to identify opportunities (Tang, et al., 2012). Student entrepreneurial alertness in this research is seen through three dimensions of entrepreneurial alertness, namely alert scanning and search, alert association and connection, and evaluation and judgment.

The first dimension is alert scanning and search which is useful in building information and finding new ideas, especially when students are looking for answers to a question. Individual basic knowledge, explicit and tacit knowledge, has a big role at this stage. Both human basic knowledge bridges the process of integrating and adopting new knowledge in new situations (Weick, 1996). Wider ability to scan and search will broaden their range of knowledge and information thereby increasing their awareness to see entrepreneurial opportunities (entrepreneurial alertness). The second dimension is the alert association and connection that is formed when students receive new information or creativity to be applied (Ghasemi \& Rowshan, 2016). Alert association and connection gives students the ability to make and associate connections between information or knowledge they have. The new information must be re-interpreted and compared with group or association information and other connections for consideration. At this stage, a recurring relationship may occur between scans and searches and association and connection. The third dimension is evaluation and judgment, the ability of students to make assessments and estimation of opportunities based on the information they have (Tang, et al., 2012). This assessment is carried out in two ways, namely attention and third-person opportunity and evaluation and first-person opportunity. When the opportunity is assessed to be positive by the student, he will dare to endure uncertainty and try the opportunity as a form of entrepreneurial action.

Students who receive entrepreneurship learning with the Stanford D School design thinking approach will do alert scans and searches for information, and they will 
practice this ability in the empathize stage. Then, they connect different knowledge and information (alert association and connection) and evaluate at the define and ideate stages. This evaluation is to match the existing information and cognitive framework for business opportunities (evaluation and judgment) trained during the prototype and test stages. The three indicators of entrepreneurial alertness have been compiled in the entrepreneurship learning design of the Stanford D School design thinking.

\section{METHOD}

This quantitative research is quasi-experiment with a nonequivalent control-group design (Budiyono, 2015). The participants included students in the marketing expertise program from two vocational schools consisting of 60 students each. The students are male and female second graders of vocational school aged 17 to 18 years. Both schools were chosen because they had passed the equality test as evidenced by the Sig. 2-tailed greater than the significant level, so students were assessed to have the same ability. There were two classes chosen from each school as the experimental class with the Stanford D School design approach and the control class with a teacher-centered approach in entrepreneurship learning. Four meetings (two hours per meeting) on entrepreneurship learning were required to apply design thinking by adjusting the stages of the Stanford D School model.

In analyzing the data, two statistical methods were used through the mean difference test (t-test). SPSS 23 application was used to test the mean difference (t-test), namely Independent Sample t-Test and Paired Sample t-Test. The mean difference test was used to determine whether there were differences in students' creativity skills and entrepreneurial alertness between the experimental class and the control class and whether there were differences in students' creativity skills and entrepreneurial alertness before and after receiving the Stanford D School design thinking entrepreneurship learning in the experimental class. All research instruments used a Likert scale with four scales (interval data) with both positive and negative statements in the form of Strongly Agree, Agree, Disagree, and Strongly Disagree statements. All instruments with a Likert measurement scale and were distributed to students during the pretest and posttest. The pretest was administered before the first meeting while the posttest was administered after the fourth meeting. Table 1 shows the research instruments that have passed the validity and reliability tests. The variable instrument is declared valid if it has a significance value of $<0.05$ and $r>$ rtable, whereas if the three research variables have a Cronbach's Alpha value of $>0.75$, it can be stated that they have good variable reliability (Priyatno, D., 2012).

Table 1

Instrument of design thinking, creativity skills, and entrepreneurial alertness

\begin{tabular}{lll}
\hline Variable & Indicator & Questions \\
\hline $\begin{array}{l}\text { Entrepreneurial } \\
\text { Alertness }\end{array}$ & $\begin{array}{l}\text { Alert scanning and search, Alert association and connection, } \\
\text { Evaluation and judgment }\end{array}$ & 22 \\
\hline Creativity Skills & Fluency, Flexibility, Originality, Elaboration & 6 \\
\hline $\begin{array}{l}\text { Design } \\
\text { Thinking }\end{array}$ & $\begin{array}{l}\text { Feedback seekers, Integrative thinking, Optimism, Experimen- } \\
\text { talism, Collaboration }\end{array}$ & 12 \\
\hline
\end{tabular}


In implementing entrepreneurship learning of Stanford d school design thinking, syllabus and lesson plan validated through expert judgment are required. The validation sheet provides an assessment of the learning sets before their application. Some elements to validate are: (1) the formulation of competency standards, basic competencies, and indicators is considered good, (2) the relevance of content or subject matter to competency standards, basic competencies, and indicators is considered very good, (3) the determination of contents referring to competency standards, basic competencies, and indicators is considered very good, (4) the formulation of learning activities following the competency standards, basic competencies, and indicators is considered very good, (5) the selection of media or learning resources following the competency standards, basic competencies, and indicators is considered very good, (6) the development of assessment tools following the competency standards, basic competencies, and indicators is considered good, (7) the learning time allotment following the competency standards, basic competencies, and indicators is considered good, and (8) the use good and correct language is considered very good. Based on the validation of the elements of the syllabus, it is concluded that the syllabus is feasible.

After the expert validation, the researcher submitted the checklist to the teacher as the supervisor and observer in reviewing each process and stage of implementing entrepreneurship learning of Stanford d school design thinking. It is to ensure that the teaching and learning process is conducted based on syllabus and lesson plan so that learning objectives can be achieved. The implementation of entrepreneurship learning with Stanford D School design thinking in the experimental class was in four meetings with the details in Table 2.

Table 2

Student activities during the Stanford D school design thinking implementation

\begin{tabular}{|c|c|c|}
\hline Meeting & Student Activities & Student Achievements \\
\hline $\begin{array}{l}\text { First } \\
\text { Meeting }\end{array}$ & $\begin{array}{l}\text { Students study marketing product promotion } \\
\text { and retail business promotion strategy } \\
\text { materials. }\end{array}$ & $\begin{array}{l}\text { Students can understand the factors, functions, } \\
\text { forms, strategies, and promotion procedures in } \\
\text { retail businesses. }\end{array}$ \\
\hline \multirow[t]{2}{*}{$\begin{array}{l}\text { Second } \\
\text { Meeting }\end{array}$} & $\begin{array}{l}\text { Empathize: Students observe minimarket users } \\
\text { at school by observing their behavior or } \\
\text { interacting through interviews and recording } \\
\text { findings. }\end{array}$ & $\begin{array}{l}\text { Students can understand the situation and gathe } \\
\text { information or problems from the perspectives } \\
\text { of others involved (users). }\end{array}$ \\
\hline & $\begin{array}{l}\text { Define: Students with groups analyze, } \\
\text { identify, and discuss the findings obtained at } \\
\text { the empathize stage. }\end{array}$ & $\begin{array}{l}\text { Students can determine the main problems } \\
\text { experienced by the users based on the } \\
\text { information collected. }\end{array}$ \\
\hline \multirow{2}{*}{$\begin{array}{l}\text { Third } \\
\text { Meeting }\end{array}$} & $\begin{array}{l}\text { Ideate: Students with groups do brainstorming } \\
\text { and incubation activities after knowing the } \\
\text { user problems. }\end{array}$ & $\begin{array}{l}\text { Students can generate ideas and solutions to } \\
\text { solve the problems experienced by users. }\end{array}$ \\
\hline & $\begin{array}{l}\text { Prototype: Students make certain designs or } \\
\text { models. }\end{array}$ & $\begin{array}{l}\text { Students can implement real ideas or solutions } \\
\text { to solve user problems (make promotional } \\
\text { media) }\end{array}$ \\
\hline \multirow[b]{2}{*}{$\begin{array}{l}\text { Fourth } \\
\text { Meeting }\end{array}$} & $\begin{array}{l}\text { Test: Students present or test promotional } \\
\text { media to users. }\end{array}$ & $\begin{array}{l}\text { Students get feedback from the users to perfect } \\
\text { the solutions and media they made. }\end{array}$ \\
\hline & Students and the teacher conclude learning. & $\begin{array}{l}\text { Students can evaluate the learning process } \\
\text { achieved and decide on the design thinking } \\
\text { stage that needs to be done again after receiving } \\
\text { feedback }\end{array}$ \\
\hline
\end{tabular}


Students in the experimental class, after going through the design thinking stage, were given the freedom to create promotional media based on the needs of minimarket users at school. The process of designing media is based on the Stanford D School design thinking which, during the process, trains student creativity skills and entrepreneurial alertness. Entrepreneurship learning in the control class used a teacher-centered approach. The teacher conducted direct learning in class by describing the material and applying questions and answers related to entrepreneurial learning material. The teacher also asked the students to create promotional media in the retail business based on the promotional media samples provided by the teacher through PowerPoints. In addition to researchers, entrepreneurship learning teachers and school mini-market users provide assessments (portfolios) on the performance of students and their class so that each stage in learning has been fulfilled per the Stanford D School design thinking.

\section{FINDINGS}

The pretest and posttest data of the control class and the experimental class were analyzed by looking at the value of the t-test or t-value. Independent Sample t-Test was employed to determine differences in the creativity skills and entrepreneurial alertness between the students in the experimental class and control class. Paired Sample t-Test was used to determine differences in the creativity skills and entrepreneurial alertness before and after receiving creative product and entrepreneurship learning with the Stanford D. School design thinking approach. Path analysis was used to examine the effect of latent variables, namely (1) the effect of entrepreneurship learning with Stanford D School approach towards creativity skills, (2) the effect of entrepreneurship learning with Stanford D School approach towards entrepreneurial alertness, and (3) the effect of creativity skills towards entrepreneurial alertness.

Table 3

$\underline{\text { Results of independent sample test on creativity skills and entrepreneurial alertness }}$

\begin{tabular}{lllll}
\hline & \multicolumn{2}{l}{ Lavene's Test for Equality of Variance } & t-Test for Equality of Means \\
\cline { 2 - 5 } & F & Sig. & t & Sig. (2 tailed) \\
\hline CS & 3.367 & 0.069 & 7.971 & 0.000 \\
EA & 0.013 & 0.910 & 6.769 & 0.000 \\
\hline
\end{tabular}

Table 3 shows the data on student creativity skills and entrepreneurial alertness between the experimental class and the control class. The data were analyzed using Equal Variance Assumed because the Sig. values of the creativity skills (0.069) and entrepreneurial alertness variables (0.910) are greater than 0.05 (Priyatno, D., 2012). The $t$ value of creativity skills (7.971) is greater than t table (2.00247), and the Sig. value ( 2 tailed) of 0.000 is less than 0.05 . It can be concluded that there are differences in the creativity skills of students between the experimental class and the control class. The $t$ value of entrepreneurial alertness (6.769) is greater than t table (2.00247), and the Sig. value ( 2 tailed) of 0.000 smaller is equal to 0.05 . It means that there are differences in student entrepreneurial alertness between the experimental class and the control class. 
Table 4

$\underline{\text { Results of paired sample test on creativity skills and entrepreneurial alertness }}$

\begin{tabular}{lccc} 
& $\mathrm{t}$ & $\mathrm{df}$ & Sig. (2 tailed) \\
\hline Creativity Skills & -3.845 & 59 & 0.000 \\
Entrepreneurial Alertness & -8.660 & 59 & 0.000 \\
\hline
\end{tabular}

Table 4 shows the data on student creativity skills and entrepreneurial alertness before and after receiving entrepreneurship learning with the Stanford D School design thinking approach. The $t$ value of creativity skills $(-3.845)$ is smaller than the table (2.00247 ), and the Sig. value ( 2 tailed) of 0.000 is less than or equal to 0.05 . It can be concluded that there are differences in student creativity skills in the experimental class before and after receiving entrepreneurship learning with the Stanford D School design thinking approach. It means that there are differences in student creativity skills in the experimental class before and after receiving entrepreneurship learning with the Stanford D School design thinking approach. The t value of entrepreneurial alertness ($8.660)$ is greater than the t table (-2.00247), and the Sig. value (2 tailed) of 0.000 is less than or equal to 0.05 . There are differences in the entrepreneurial alertness of students in the experimental class before and after receiving entrepreneurship learning with Stanford D School design thinking

\section{DISCUSSION}

The findings demonstrate differences in creativity skills and entrepreneurial alertness between experimental and control class students as well as in creativity skills and entrepreneurial alertness of experimental class students before and after receiving learning with Stanford D School design thinking. The independent sample test shows the Sig. value of Lavene Test of creativity skills (0.069) and entrepreneurial alertness (0.910) is greater than 0.05 . Likewise, the value of $t$ of creativity skills (7.971) and entrepreneurial alertness (6.769) is greater than ttable (2.00247). Besides, the Sig. value ( 2 tailed) of both variables is 0.000 , less than 0.05 . Paired samples t-test shows the $t$ value of creativity skills (-3.845) and entrepreneurial alertness (-8.660) is less than ttable $(-2.00247)$, and the Sig. value (2 tailed) of both variables is 0.000 . This proves that students who receive entrepreneurship learning with Stanford D School design thinking have different entrepreneurial creativity and alertness skills from those learning entrepreneurship with conventional approach. Besides, there are differences in creativity skills and entrepreneurial alertness of experimental class students before and after receiving entrepreneurship learning with Stanford D School design thinking. The results of the research prove that design thinking can be applied in entrepreneurship learning in vocational schools to train students' creativity skills and entrepreneurial alertness. This is in line with the results of previous research reporting that design thinking learning can improve student creativity skills and entrepreneurial alertness (Aflatoony \& Wakkary, 2015; Campos, 2016; Ghasemi \& Rowshan, 2016; Henriksen, D., et al., 2017; Hu, R., et al., 2018; Luka, 2014; Val, E et al., 2019).

Stanford D School model was used to introduce students to entrepreneurship learning based on design thinking in vocational schools, which has never been studied before. In 
general, the results showed that there were differences in students' creativity skills and entrepreneurial alertness between the control class and the experimental class. In control class learning, teachers have an important role in the learning process so that learning objectives can be achieved. Learning begins with the presentation of the problems provided by the teacher in the classroom to be solved, namely the problems of school mini-market users. Students are given the freedom to find solutions to problems by searching the Internet or discussing with friends. Unfortunately, the problems of mini market users are not based on the real problems but are only limited to the teacher's assessment and description. Control class students develop creativity skills, but the limited information on the problems faced by users makes students' creativity skills develop less optimally like the outputs and solutions produced by students during learning. These outputs are limited to solving problems that are presented in class and are not applied in everyday life. Students in the experimental class with entrepreneurship learning based on Stanford D School design thinking have the responsibility and are actively involved in the process of collaboration, observation, identification, and brainstorming after interacting with users. In this research, it can be seen from the second meeting in empathize and define activities (Table 2) that students gain new knowledge and information by understanding users through interactions and interviews related to their constraints as consumers at school mini markets. Then, at the third meeting in ideate and prototype activities (Table 2), students carry out group discussions to train their creativity and cooperation to find solutions to user problems.

In contrast to the teacher-centered learning approach in the control class, entrepreneurship learning with Stanford D School design thinking in the experimental class requires students to look for and find problems that exist directly through interaction with users (Val, E. et al., 2019), so that the teachers do not present problems during learning. Therefore, students not only understand entrepreneurship learning materials but also practice creativity skills and entrepreneurial alertness. Stanford D School design thinking activities encourage students to creatively formulate problems and look for ideas and solutions to the problems. Stanford D School design thinking activities in entrepreneurship learning, especially at the ideate stage, offer solutions, ideas, and products to users (Table 2) as one of the outputs of experimental class students during the learning process based on the user's needs to overcome these problems. The output may be ignored by others but can be captured by students who have gone through the process of empathizing and defining with users. This stage trains students' ability to look for opportunities in the surrounding environment. The findings of problems during the learning process also hone the ability of opportunity recognition that leads to student entrepreneurial alertness (Val, E. et al., 2019).

The results of this research also prove that students in the experimental class have different creativity skills and entrepreneurial alertness after receiving entrepreneurship learning with Stanford D School design thinking. Learning with Stanford School D School offers experiential learning where the learning process occurs when knowledge is created through the transformation of experience (Clark, et al.,2010). New experience gained by the students makes the process of observation or reflection that can guide the ability to create concepts and use theories to solve problems (Nasution, 2017: 111). The 
problem-analysis activity aims to increase student sensitivity in capturing phenomena that arise from various aspects to be more responsive to opportunities. Students in the experimental class who have gone through the entrepreneurship learning process with the Stanford D School design thinking have the skills to identify opportunities, it is most likely for them to use these skills in daily life. Identifying opportunities is the beginning of the entrepreneurial process and an indication of one's creative behavior (Aflatoony \& Wakkary, 2015). Entrepreneurial alertness reflects an individual ability to combine information that is not interconnected but has a strong relationship (Campos, 2016). Creativity plays an important role in entrepreneurship such as creating new products in the market, innovating, and allowing alternative use of resources (Hu, R., et al., 2018). In this research, students who learned with Stanford D School design thinking were able to use their creativity to develop and produce marketing promotion media based on the needs of the school community so that they could be a solution to these problems. Experimental class students who were previously in conventional learning were less able to develop their creativity in producing products. In addition to proving the differences in creativity skills and entrepreneurial alertness between the control and experimental classes, this research presents how Stanford D School design thinking is applied to entrepreneurship learning in vocational schools, which has never been studied before.

\section{CONCLUSION}

The results of this research prove that there are significant differences in creativity skills and entrepreneurial alertness between the experimental class and the control class and the creativity skills and entrepreneurial alertness of the experimental class after receiving entrepreneurship learning with the Stanford D School design thinking approach. Stanford D School design thinking learning allows students to use the new information and knowledge they build up during the entrepreneurship learning process. Each stage in the learning process encourages students to make observations and reflections so that they can be used to solve problems. Therefore, it is not surprising that student learning experiences become central in the learning process, especially in design thinking. Creativity skills are naturally formed during the design thinking process when students build knowledge based on information and learning experience stored in their memory, which are then processed and stored to be reused, especially during discussion and identification.

This research also proves that design thinking can be applied in education, especially in vocational school learning, one of which is entrepreneurship learning. Design thinking as a learning approach also provides several new insights which are summarized into two aspects. First, the application of design thinking increases the relationship between a teacher and his students. Entrepreneurship learning can be taught with a designer approach that combines "what" and "how" into "value"; therefore, entrepreneurship learning cannot be taught using conventional learning methods. However, design thinking still involves the role of the teacher as a facilitator who gives direction to students so that the learning process remains directed and can achieve learning goals. Second, a comfortable and pleasant learning environment can be created through design thinking. In addition to the freedom of thinking and meaningful learning experience, 
students can develop creative-thinking frameworks by integrating knowledge and action. They are given the opportunity to take the initiative in every step of design thinking, reflecting, finding solutions with their ideas, and producing something useful for others. Therefore, during learning, students not only gain and transfer knowledge but also provide benefits to those around them.

This research is limited to a small group of subjects, vocational school students, so it is suggested that further research be conducted on a larger scale to strengthen research results. Besides, this research has not reviewed the effect of design thinking on personality characteristics (e.g., self-efficacy and locus of control) and how design thinking can develop entrepreneurial alertness through three dimensions (alert scanning and search, alert association and connection, and evaluation and judgment) in depth. It is hoped that educational institutions and teachers will be willing to support the application of this new learning approach and model as an educational culture to train entrepreneurial competencies and skills that are urgently needed, especially for vocational schools.

\section{REFERENCES}

Aflatoony, L., \& Wakkary, R. (2015). Thoughtful Thinkers: Secondary Schoolers' Learning about Design Thinking. Proceedings of 3rd International Conference for Design Education Researchers: LearnxDesign, 2, 563-574.

Anderson, L.W. \& Krathwohl, D.R. (2001). A Taxonomy for Learning, Teaching, and Asessing: A Revision of Bloom's Taxonomy of Educational Objectives. A Bridged Edition. New York: Addison Wesley Longman, Inc.

BPS. (2019). Berita Resmi Statistik Keadaan Ketenagakerjaan Indonesia Februari 2019.

Blenker, P., Korsgaard, S., \& Neergaard, H. (2011). The questions we care about: paradigms and progression in entrepreneurship education. Industry and Higher Education, 25(6), 417-427. https://doi.org/10.5367/ihe.2011.0065

Boyles, T. (2012). 21st century knowledge, skills, and abilities and entrepreneurial competencies: A model for undergraduate entrepreneurship education. Journal of Entrepreneurship Education, 15, 41-56.

Budiyono. (2015). Statistika Untuk Penelitian (Edisi ke-2). Surakarta: UNS Press.

Campos, H. M. (2016). O papel da criatividade na mediação do relacionamento entre a paixão empreendedora e a prontidão empreendedora. Revista Brasileira de Gestao de Negocios, 18(61), 457-472. https://doi.org/10.7819/rbgn.v18i61.3010

Clark, R. W., Threeton, M. D., \& Ewing, J. C. (2010). The potential of experiential learning models and practices in career and technical education \& career and technical teacher education. Journal of Career and Technical Education, 25(2). http://doi.org/10.21061/jcte.v25i2.479. 
Corebima, A. D., Susilo, H., \& Zubaidah, S. (2017). Creative thinking of low academic student undergoing search solve create and share learning integrated with metacognitive strategy. International Journal of Instruction, 10(2), 245-262.

D.School. (2019b). Teaching and Learning. Retrieved October 10, 2019, from Hasso Plattner Institute of Design at Stanford University website: https://dschool.stanford.edu/programs/teaching-learning

Dam, R., \& Siang, T. (2019). What is Design Thinking and Why Is It So Popular? Retrieved from Interaction Design Foundation.

Deutschmann, M., \& Botts, M. (2015). Experiential learning through the design thinking technique. The Palgrave Handbook of Experiential Learning in International Business, 449-450.

Dorst, K. (2011). The core of 'design thinking' and its application. Design Studies, 32(6), 521-532. https://doi.org/10.1016/j.destud.2011.07.006

Drapeau, P. (2014). Sparking Student Creativity: Practical Ways to Promote Innovative Thinking and Problem Solving. Retrieved from www.ascd.org

Dyer, J., Gregersen, H., \& Christensen, C. M. (2011). The Innovator's DNA: Mastering the Five Skills of Disruptive Innovators. Harvard Business Press.

Garrett, T. (2008). Student-centered and teacher-centered classroom management: A case study of three elementary teachers. Journal of Classroom Interaction, 43(2004), 34-47.

Ghasemi, B., \& Rowshan, A. (2016). The factors contributing to entrepreneurial alertness. International Journal of Modern Research in Engineering and Technology, 10 (March).

Hamidi, D. Y., Wennberg, K., \& Henrik, B. (2008). Creativity in entrepreneurship education. Journal of Small Business and Enterprise Development, 15(2), 304-320. https://doi.org/10.1108/14626000810871691

Henriksen, D., Richardson, C., \& Mehta, R. (2017). Design thinking: A creative approach to educational problems of practice. Thinking Skills and Creativity, 26(October), 140-153. https://doi.org/10.1016/j.tsc.2017.10.001

Hu, R., Wang, L., Zhang, W., \& Bin, P. (2018). Creativity, proactive personality, and entrepreneurial intention: The role of entrepreneurial alertness. Frontiers in Psychology, $9,1-10$

Igwe, P. A., Okolie, U. C., \& Nwokoro, C. V. (2019). Towards a responsible entrepreneurship education and the future of the workforce. The International Journal of Management Education, (August 2018), 0-1.

Kementerian Koperasi dan UKM (2020). Kemenkop dan UKM Berharap Lulusan Perguruan Tinggi Dituntut Berkarya Kreatif dan Inovatif. Retrieved from http://kemenkopukm.go.id/ 
Kemendikbud. (2017). Higher-Order Thinking Skills (HOTS). Retrieved from http://slideplayer.info/slide/12409112.

Krathwohl, D. R. (2002). A revision of Bloom's taxonomy: An overview. Theory into practice, 41(4), 212-218.

Krulik, S., \& Rudnick, J. A. (1999). Innovative tasks to improve critical and creative thinking skills. Dalam Lee V. Stiff \& Frances R. Curcio (Editor), Developing mathematical reasoning in grades K12,1999 yearbook. Reston, VA: The National Council of Teachers of Mathematics, Inc.

Li, R., Qian, Z. C., Chen, Y. V., \& Zhang, L. (2019). Design thinking driven interdisciplinary entrepreneurship. A Case Study of College Students Business Plan Competition. Design Journal, 22(sup1), 99-110.

Linton, G., \& Klinton, M. (2019). University entrepreneurship education: a design thinking approach to learning.

Luka, I. (2014). Design thinking in pedagogy. Journal of Education Culture and Society, (2), 63-74. https://doi.org/10.15503/jecs20142.63.74

McIntyre, J., \& Roche, M. (1999). University education for entrepreneurs in the United States: A critical and retrospective analysis of trends in the 1990s. Georgia Institute of Technology.

Nasution, S. (2017). Berbagai Pendekatan Dalam Proses Belajar \& Mengajar (Cetakan ke). Jakarta: PT. Bumi Aksara.

Nielsen, S. L., Lassen, A. H., Nielsen, L. M., \& Mikkelsen, M. (2013). Opportunity design: understanding entrepreneurial opportunities through design thinking. International Entrepreneurship and Management Journal.

Presseisen, B. Z. (1985). Thinking skills: meanings and models. Dalam Arthur L. Costa (Edited), Developing minds: A resource book for teaching thinking (pp. 43-48). Alexandria, Virginia: ASCD.

Piirto, J. (2011). Creativity for 21st. In Sense Publishers. Retrieved from https://link.springer.com/chapter/10.1007/978-94-6091-463-8_1

Priyatno, D. (2012). Belajar Praktis Analisis Parametrik dan Non Parametrik Dengan SPSS. Yogyakarta: Penerbit Gava Media.

Rowe, P. G. (1987). Design Thinking. MIT press.

Saputra, M. D., Joyoatmojo, S., Wardani, D. K., \& Sangka, K. B. (2019). Developing critical-thinking skills through the collaboration of jigsaw model with problem-based learning model. International Journal of Instruction, 12(1), 1077-1094.

Sarooghi, H., Sunny, S., Hornsby, J., \& Fernhaber, S. (2019). Design thinking and entrepreneurship educa - where are we, and what are the possibilities? Journal of Small Business Management, 57, 78-93. 
Singh, C. P. (2006). Introduction to educational technology. New Delhi: Lotus Press.

Tang, J., Kacmar, K. M. M., \& Busenitz, L. (2012). Entrepreneurial alertness in the pursuit of new opportunities. Journal of Business Venturing, 27(1), 77-94.

Tu, J. C., Liu, L. X., \& Wu, K. Y. (2018). Study on the learning effectiveness of stanford design thinking in integrated design education. Sustainability (Switzerland), 10(8), 1-21. https://doi.org/10.3390/su10082649

UU RI No. 20, 2003. (2003). Undang-Undang Nomor 20 Tahun 2003 tentang Sistem Pendidikan Nasional. Sekretariat Negara. Jakarta.

UCLES. (2019). Developing the Cambridge Learner Attributes. Retrieved from Cambridge Assessment International Education website.

Val, E., Gonzalez, I., Iriarte, I., Beitia, A., Lasa, G., \& Elkoro, M. (2017). Entrepreneurship education in european school curricula a design thinking approach to introduce entrepreneurship education in European school curricula. The Design Journal, 20(1), 754-766. https://doi.org/10.1080/14606925.2017.1353022

Val, E., Gonzalez, I., Lauroba, N., \& Beitia, A. (2019). How can design thinking promote entrepreneurship in young people?. The Design Journal, 22(sup1), 111-121.

Valliere, D. (2013). Towards a schematic theory of entrepreneurial alertness. Journal of Business Venturing, 28(3), 430-442. https://doi.org/10.1016/j.jbusvent.2011.08.004

Van Gelderen, M., Kautonen, T., \& Fink, M. (2015). From entrepreneurial intentions to actions: Self-control and action-related doubt, fear, and aversion. Journal of Business Venturing, 30(5), 655-673.

Vygotsky, L. S. (1967). Play and Its Role in the Mental Development of the Child. Soviet Psychology, 5(2), 6-18.

Weick, K. (1996). Drop your tools: an allegory for organizational studies. Administrative Science Quarterly, 41, 301-3014.

World Economic Forum. (2018). The Future of Jobs Report 2018. In Weforum.org. https://doi.org/10.1177/0891242417690604

Wrigley, C., Mosely, G., \& Tomitsch, M. (2018). Design thinking education: a comparison of massive open online courses. She Ji: The Journal of Design, Economics, and Innovation, 4(3), 275-292. https://doi.org/10.1016/j.sheji.2018.06.002

Zampetakis, L. A., Gotsi, M., Andriopoulos, C., \& Moustakis, V. (2011). Creativity and entrepreneurial intention in young people. The International Journal of

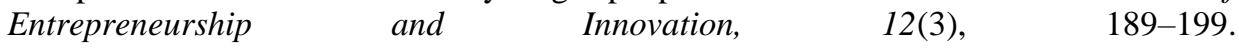
https://doi.org/10.5367/ijei.2011.0037 